\title{
Manitoba's unique health care burdens stall federal deal
}

\author{
Cite as: CMAJ 2017 June 26;189:E873-4. doi: 10.1503/cmaj.1095443
}

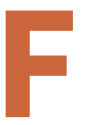
or nearly three months, Manitoba has stood alone. Every other jurisdiction in Canada has signed a health care deal with the federal government. But Manitoba Premier Brian Pallister remains defiant, saying that negotiations are ongoing, but the deal offered by the federal government is "bad" and will "continue to be a bad deal whether 10 provinces sign it or nine."

The two main issues that Pallister wants the federal government to address are funding for diabetes and Indigenous health care. Some health experts in Manitoba agree with the premier that these issues are uniquely important in the province.

Manitoba has a unique burden with regards to diabetes in the Indigenous population, according to Alan Katz, director of the Manitoba Centre for Health Policy. The rates of type 2 diabetes in Indigenous youth and adolescents are extremely high, he said, and the associated health care costs are considerable.

The Indigenous population forms a higher percentage of the total population than in any other province, noted Katz. Also, a high percentage of the Indigenous population lives in isolated areas, which makes access to health care and transportation costs a major issue.

"So with this background, each Manitoban will make their own assessment of the premier's approach to this negotiation," said Katz. "I suspect that he will be seen as a hero if he gets what he is demanding; and Manitobans will be pretty upset if the gamble does not pay off and we do not get the increased transfers on the table."

The premier is indeed doing the right thing, according to Dr. Jan Hux, chief science officer for Diabetes Canada. "Diabetes Canada commends the Government of

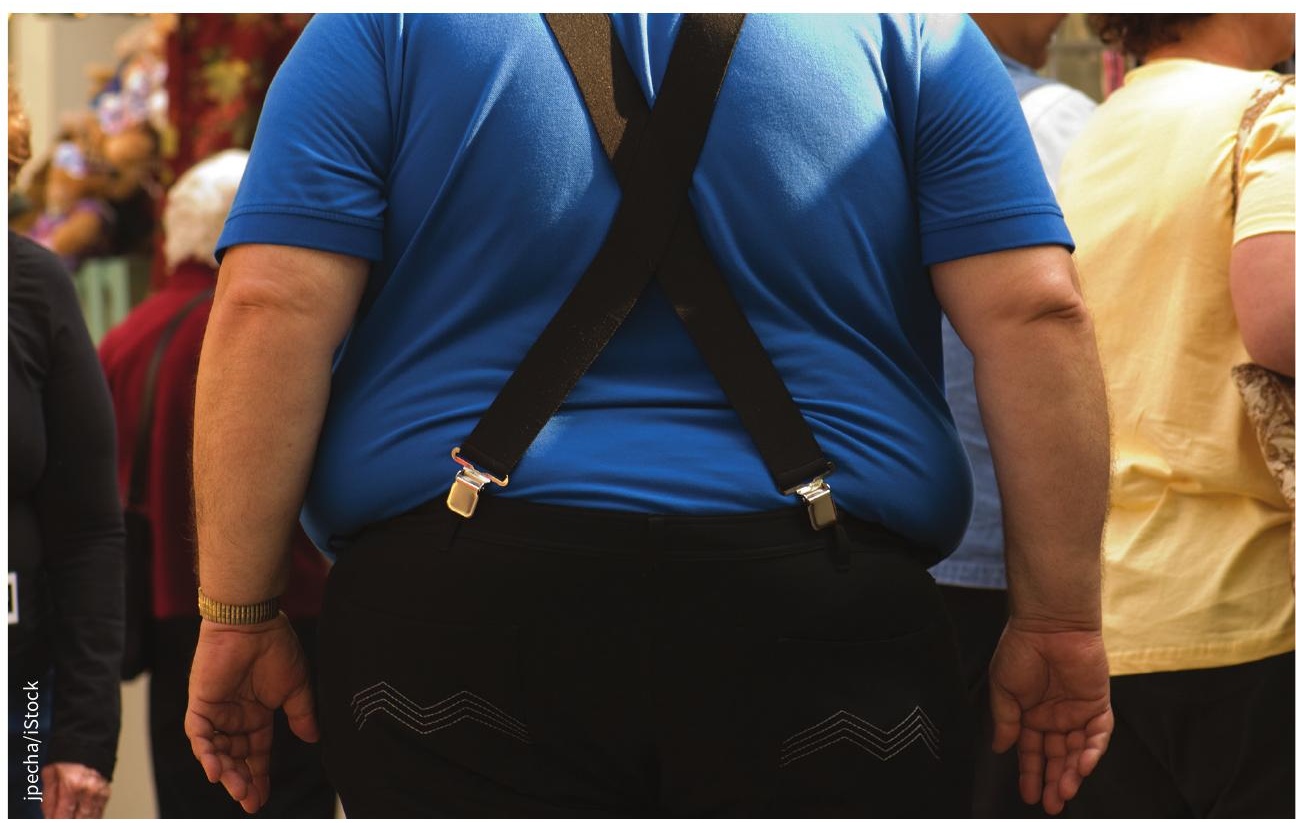

Higher-than-average obesity rates are contributing to high prevalence of diabetes in Manitoba.

Manitoba for taking a strong position on the need for dedicated federal funding targeted to diabetes in the province," said Hux.

Diabetes or prediabetes affects $28 \%$ of Manitobans, about 373000 people, and is expected to increase to $31 \%$ by 2026 , according to the organization's report Diabetes in Manitoba. Half of people with prediabetes will develop type 2 diabetes without intervention, states the report, which estimates that annual out-ofpocket costs for Manitobans with type 1 diabetes is $\$ 2244-\$ 6186$ and for type 2 diabetes is $\$ 1930$.

"Diabetes also places a burden on the economy, costing Manitoba's health care system $\$ 114$ million a year in added costs, including hospitalizations, doctor visits and inpatient medications," said Hux.

The report also notes that Manitoba has a lower median family income and higher rates of obesity than the national average, and that $16.7 \%$ of the province's population is Aboriginal. Type 2 diabetes is more prevalent among the Indigenous population, is diagnosed at younger ages, and leads to poorer outcomes than in the general population.

"Indigenous Peoples also face multiple barriers to preventing and effectively managing diabetes, such as food insecurity, high food prices, high prevalence of risk factors that contribute to type 2 diabetes, poor access to programs and services, lack of proper infrastructure and a wide range of social determinants of health," said Hux. "These barriers also contribute to higher rates of diabetes complications among Indigenous peoples in Manitoba."

The federal government's focus, however, has been on home care and mental health, not diabetes. According to Andrew MacKendrick, press secretary for the Office of the Minister of Health, the fed- 
eral government remains focused on these areas and hopes Manitoba will sign a deal similar to those accepted by the other provinces and territories.

"We have made a historic \$11-billion offer to the provinces and territories to provide better health care for all Canadians, and we have been able to reach agreements with all 12 other jurisdictions," said MacKendrick. "It is our hope that we will be able to reach an agreement with Manitoba to ensure Manitobans see the benefits of these investments in home care and mental health."
So far, the negotiations between Manitoba and the federal government, while unsuccessful, have been full of drama. There were allegations that the federal government had threatened to withhold $\$ 60$ million already promised for a hightech project in Winnipeg over Pallister's refusal to sign a health care deal. Pallister acknowledged those allegations, stating that the "withdrawal of previous commitments is not something that emboldens character or smacks of integrity."

In Manitoba, the premier was criticized by Manitoba Keewatinowi Okimakanak, a
First Nations advocacy group, for not consulting with them on how to improve Indigenous health care in the province.

"If they do have a plan, I wish they would share it with us so we can collaborate," Sheila North Wilson, grand chief of the advocacy group, told CBC News. Pallister was also accused of unleashing "old union guy" rhetoric during the negotiations with the federal government in an editorial by the Winnipeg Free Press, which stated that the premier's schtick was getting old.

Roger Collier, CMAJ 